\title{
Religious work environment - benefit or challenge? A qualitative study on motivation at work in a religiously affiliated hospital
}

\author{
Ann-Kathrin Seemann* \\ Department for Public and Non-Profit Management, University of Freiburg, Germany
}

Received: June 13, 2016

DOI: $10.5430 /$ jha.v5n5p106

\author{
Accepted: August 12, 2016 \\ Online Published: August 17, 2016 \\ URL: http://dx.doi.org/10.5430/jha.v5n5p106
}

\begin{abstract}
Workplace spirituality and faith are important and emerging trends in business that should direct managers' attention for various reasons. Therefore, this qualitative study asks whether a religious work environment provides a beneficial or challenging factor for an organization. It examines the particular work environment of a faith-based hospital and its effects on employees' motivation and work ethics. The study adopts a qualitative approach, using semi-structured interviews. The interviews were conducted with human resources (HR) staff and nurses of an Adventist Hospital in the USA. The interviewees were purposefully selected to learn about their individual perspectives. The findings indicate that religiously affiliated organizations attract a special type of employee with a certain work ethic. The respectful, friendly and helpful treatment of colleagues amongst each other is one of the biggest differences when compared to non-faith-based organizations. Additionally people are more altruistic, humble and dedicated. In addition, the community outreach and the chance to support patients, both medical and spiritual, gives the work a special meaning. However, the study also indicates some challenges due to the religious affiliation, especially in the case of tough business decisions. Thus understanding the special features of a religiously affiliated organization and its effects on employees might help secular organizations to provide a spiritual working environment for their employees to take advantage of the beneficial effects without having to deal with the identified weaknesses.
\end{abstract}

Key Words: Religious work environment, Faith-based hospital, Work ethics, Motivation to work, Workplace spirituality

\section{INTRODUCTION}

In the past years a growing interest in the role of religious dimensions and factors in business life was observable. ${ }^{[1]}$ Usually, people spend a large proportion of their life at work. Their social inclusion and recognition are being considerably influenced by their job choice, their work environment and their co-workers. On this basis, people seek value, support and meaning at work ${ }^{[2,3]}$ and in their life. They expect their work environment to be a place that allows to reveal and express their entire selves instead of leaving parts of their identity in front of organizational doors. As described by Miller and Ewest, ${ }^{[4]}$ more and more employees in all types of organizations begin to integrate their faith and spirituality in the workplace and their daily working routine wherever it is feasible and reasonable. This includes for example an increase in prayer groups for business people. ${ }^{[5]}$

Motivation to work and the antecedents of organizational outcomes have been issues of great interest for the past few

\footnotetext{
*Correspondence: Ann-Kathrin Seemann, Prof.; Email: ann-kathrin.seemann@ vwl.uni-freiburg.de; Address: Department for Public and Non-Profit Management, University of Freiburg, Germany.
} 
decades and are still of high importance. Currently, in the uncertain economic environment, most organizations, especially in the nonprofit sector, feel the pressure to operate more efficiently while reducing costs at the same time. Motivational theories provide information on how job performance and efficiency can be increased. Even against the background of a lack of skilled employees, motivation at work plays an important role. The situation especially prevails to a large extent in the healthcare sector. Nursing shortage is a problem that occurs worldwide. Low recruitment and high turnover rates are a well-known problem ${ }^{[6]}$ and the need for taking action to retain and attract skilled labour is clearly evident.

Against this background, providing a motivating and stimulating working environment is an important and challenging role for any manager. Work motivation can be defined as "(...) a set of energetic forces that originate both within as well as beyond an individual's being, to initiate work-related behavior and to determine its form, direction, intensity, and duration". ${ }^{[7]}$ A lack of motivation amongst employees is often attributable to the ethical working climate of an organization. ${ }^{[8]}$ A positive perceived working climate results in productive in and high standards of conduct and is therefore jointly responsible for productive and motivated behavior. Moreover, Wuthnow ${ }^{[9]}$ indicated the emergence of a postmaterialist era, with the consequence that people are no longer satisfied by only money and belongings but grasp at new individual values of autonomy, personal fulfilment and self-expression. Understanding and managing to implement these particular value concepts can therefore provide a basis to reduce turnover rates, strengthen employees' loyalty and keep them motivated.

One motivating factor is assumed to be found in transcendental approaches and faith. It is important to distinguish religion, which refers to a set of beliefs a rituals, and spirituality, which is associated with the desire for meaning, deeper values, ${ }^{[3]}$ a sense of wholeness and connectedness. ${ }^{[10]}$ Nonetheless, spiritual nourishment can arise from a religious background, ${ }^{[10]}$ as the boundaries between these two are sometimes blurred. Religion, with its beliefs and prayers, can be a means through which one can explore one's spirituality, and it is supposed to provide spirituality with more depth and discipline. ${ }^{[5]}$ According to Duchon and Plowman, ${ }^{[3]}$ religion offers a context through which individuals can pursue their spirituality. Religion and spirituality are often an absolute taboo topic in in the corporate environment. However, Pargament and Magyar-Russell ${ }^{[11]}$ emphasized the strong influence religion has on factors such as personality, health, emotions and virtue, and therefore on the motivation to perform. Spirituality, whether religious or non-religious, is recognized as giving meaning to a person and the world ${ }^{[12]}$

Published by Sciedu Press and according to the study of Milliman and Czaplewski, ${ }^{[10]}$ workplace spirituality has a significant positive effect on factors, such as intrinsic work satisfaction and organizational commitment. Additionally, Garcia-Zamor ${ }^{[2]}$ found that a spiritual workplace leads to an environment that supports happiness and increased performance. Longenecker and McKinney ${ }^{[1]}$ assumed an influence of religious beliefs on handling ethical issues in business, because believers follow certain principles. Therefore, it can be considered an essential factor in ethical business decision-making. Hence, I assume that a religious working environment provides a fruitful basis for a satisfying and highly efficient working climate that enables a loyal commitment to the organization.

Another worthwhile subject to explore arises from the question of whether a religious work environment attracts a certain type of employee with particularly high ethical standards and social values. Numerous studies over the past few decades have presented evidence that an increased motive to serve the public good is prevalent in the public sector workforce. ${ }^{[13,14]}$ The influence of public service motivation on job satisfaction, turnover rates, organizational commitment and performance was examined and explained with varying degrees. Wright and Grant ${ }^{[15]}$ summarized that people with higher public service motivation are more likely to work for public organizations because they obtain satisfaction through providing public service, which results in an overall better job performance. In his study, Light ${ }^{[16]}$ indicated stronger motivation and higher satisfaction linked to meaningfulness of the work for employees in the nonprofit sector as well, even though they often have to contend with less payment compared to private organizations, and often excessive and emotional workloads.

Understanding the distinctive characteristics of a faith-based organization and the resulting effects on employees is supposed to help secular organizations accommodate the desire for combining faith and wok by providing a work environment akin to those of religious organizations.

The existence of a religious added value that can be found in faith-based organizations ${ }^{[17]}$ provided the basis for this research. The study of Seemann et al. ${ }^{[17]}$ indicated that the presence of religious traits leads to greater overall satisfaction among patients and employees. In addition it helps to strengthen patients' perceptions of trustworthiness and enhances the competiveness of the organization. Few qualitative and quantitative studies explore the phenomenon of a religious work environment on employees' motivation to work, their job satisfaction, their organizational commitment and organizational performance. ${ }^{[17,18]}$ Therefore, this study fills a research gap by answering the following research ques- 
tions:

RQ 1: Does a religious work environment attract a certain type of employee with particularly high standards and social values?

RQ 2: To what extent does the religious affiliation of an organization affect organizational and employees' performance?

RQ 3: Does a religious work environment represent a benefit or a challenge for both employees and management?

\section{Methods}

\subsection{Study area}

Faith-based organizations range from small local companies to powerful and influential corporate groups. Especially in the healthcare and nursing sector, they became an indispensable part of the work. Religiously affiliated nonprofit hospitals play an important role in Europe, e.g., in Germany, where $85 \%$ of all nonprofit hospitals have a religious background. Even more important are faith-based hospitals in the US where they support the healthcare of millions of Americans and provide a type of safety net for the poor and vulnerable. ${ }^{[19]}$ They are committed to the concept of social welfare, as they have to follow their moral concepts and mission, but they must also be competitive and keep their business viable, ${ }^{[20]}$ which results in an often conflicting situation.

The religious background of an organization can be understood as a multidimensional construct including specific beliefs, behaviours, rituals and rules. ${ }^{[21]}$ Therefore, a basic distinction among daily routine is observable when comparing a faith-based and a non-faith-based organization.

Berger $^{[22]}$ described religious organizations as a "unique hybrid of religious beliefs and sociopolitical activism". For this reason, a religiously affiliated hospital was chosen as the social background for this study.

The interviews were conducted among employees in a nonprofit hospital belonging to Adventist Health Systems in the southeast USA in December 2013. The Seventh-day Adventist Church is a Protestant Christian denomination distinguished by its observance of Saturday. Their members believe in the imminent return of Jesus Christ. Adventist Health System owns and manages hospitals, nursing homes, home health agencies, health care systems and an array of other services. With 45 hospitals located across the USA, the Adventist Health System is the largest not-for-profit Protestant hospital system in the country. It is a faith-based health-care organization with more than 74,000 employees maintaining a tradition of caring for the physical, emotional and spiritual needs of every patient. ${ }^{[23]}$ Their mission is to "Extend the healing ministry of Christ". They state that: "We exist to serve the needs of our communities in harmony with Christ's healing ministry and incorporate Christian values at every level of service."

The aim of the study was to explore the views of a range of Human Resources (HR) professionals and employees on the overall working climate, the motivation to work and possible challenges in a faith-based environment. An influencing effect of a religiously affiliated work environment on the type of employee it attracts is assumed, and therefore it is timely and relevant to talk to both groups. Individual interviews with eight HR professionals and eight nurses were conducted to learn about their individual perspectives regarding motivation to work in a nonprofit faith-based environment. The median working experience of the participants is 22 years and 12 of the participants have worked in a secular environment before working for Adventist Health Systems. Sample characteristics can be found in Table 1. The interviews were conducted as semi-structured interviews. Semi-structured interviews consist of several key questions that help to define the areas to be explored but also allow the interviewer to diverge in order to pursue an idea or response in more detail. The informants were selected based on their area of operation. An interview guide was used during the interviews. Each interview lasted approximately 45 minutes to an hour.

Table 1. Sample characteristics

\begin{tabular}{lll}
\hline Variable & & $\mathbf{N}$ \\
\hline \multirow{2}{*}{ Occupational area } & Nurse & 8 \\
& Human Resources & 8 \\
Sex & Female & 9 \\
& Male & 7 \\
\multirow{2}{*}{ Denomination } & Adventist & 6 \\
& Other & 10 \\
\hline
\end{tabular}

\subsection{Data analysis}

Data were analysed according to areas covered. The audiorecorded interviews were subsequently transcribed verbatim following predefined rules and analysed thematically for the identification of central issues using MAXQDA 11 software. Therefore, a double coding was used to minimize subjective bias. The transcript codings were compared and discrepancies between the coders discussed. The coding scheme included code name and definition, text examples and coding rules. The analytical approach was based on a mixture of deductive and inductive methods.

\section{RESULTS}

Depending on the situation, the interviewees agreed that the religious work environment is promoting a healthy climate and enjoyable surrounding, in which one is gladly to go to work. There are several factors worth mentioning that were 
influenced by the religious affiliation of the observed hospital, either in a good way or in a less favourable way. As motivating and positive, factors such as spiritual nourishment that arose from the religious work environment, the overall warm and familiar working climate, humble and dedicated co-workers, benefits and securities for the staff, and the feeling that the human is the focal point instead of the business, were mentioned. Participants also indicated that management, patients and employees are setting themselves high standards, their work and their behaviour due to the religious affiliation which results in a more effective way of working. However, certain challenges were also noted with respect to a faith-based working environment. Some of the informants alluded to a too compassionate management that is therefore incapable of holding employees accountable for possible missteps. Additionally the feeling that employees of the same faith, here Adventist, are preferred to be promoted did not support a satisfying working climate. The findings are discussed in detail as follows.

\subsection{Who is attracted by a faith-based nonprofit hospi- tal?}

Especially in times when qualified people are in short supply, it is important to understand who is attracted by a certain type of organization and why. The assessment of employees' motivation to work, is an additional crucial factor for corporate success. Following the managerial sorting theory of Weisbrod, ${ }^{[24]}$ public and nonprofit organizations attract different types of employees than private ones that are driven by varying goals, values and moral concepts. Based on the public service motivation theory, the literature confirms that people who are working in the public or nonprofit sector are driven by an intrinsic motivation instead of extrinsic incentives. This is because performance assessment in these sectors is mostly poor and materialistic incentive systems are often insufficient or inexistent due to the often vague goals of public organizations. ${ }^{[14]}$ People with distinctive public service motivation grow in their community based work as they get the chance to do something meaningful and make their full contribution to society. ${ }^{[15]}$ The existence of this intrinsically rewarding feeling was confirmed by several participants of the study in varying degrees. In the following you can see answers from two nurses regarding the question of what their motivation is to come to work and do their job with a consistently high standard:

"What is my motivation? Probably helping people. Caring for people. Knowing that you can make their burden a little bit lighter, the pain a little bit less. That's number one." (Nurse)

"The most important factor of motivation... I just think the

Published by Sciedu Press reason I do this job is because I care about people. And I want to help them feel better, do better. That's probably the biggest motivator." (Nurse)

According to the study of Ben-Ner and Ren ${ }^{[25]}$ non-profit and public sector employees receive less compensation when compared to their colleagues working in the private sector. Moreover there are less financial incentives like bonuses or pay per performances systems which is due to the nondistribution constraint. This constraint prohibits the profit distribution to stakeholders and requires the reinvestment into the organization. With regards to the arguments raised by the public service motivation theory, the lower payment compared to a position in a for-profit hospital or other corporate environment was not necessarily perceived as negative.

"When you come here, I think you have to recognize that the payment may not be comparable to what you receive in a secular workplace. However, you receive so much more. You receive more satisfaction and I think you have more peace within work versus a secular." (Nurse)

In fact, most of the participants stated that other values such as the warm, trustful and familiar atmosphere carry more weight than higher remuneration.

Religious pluralism is not a problem either. Despite the sometimes prevailing public opinion that one has to be Adventist to work or be treated in the hospital, all cultures and religions are welcome. Indeed, there is a broad variety of religions among the employees of the hospital. Nonetheless, everybody has to feel comfortable working in a religious environment.

"All staff has to be comfortable working in a Christian organization. Meaning when we talk about our patients, and when we talk about things going on in the hospital, it's often if not always tied back to the mission. So, for someone to work here, they have to be ok with that. They have to understand what Christ's mission was, what his reason for being here was, and why we are extending that on a daily basis." (HR)

Participants also confirmed that there are people looking exactly for that type of organization to work in, because for them, the benefits of working in a faith-based environment outweigh, for example, lower payment.

"The faith-based makes the difference in the people that you encounter, because you can work here if you are not a believer. But you can't work in this environment and be not surrounded by individuals who are believers and not be impacted by it." (HR)

"So I think that our staff ...overall, not always but overall I think they understand why we are here and they chose to 
work here because it is a Christian organization. And not because we pay them the most or because some other reason. But they enjoy working in a faith-based organization.” (HR)

Overall, I can assume that comparable to public sector motivational theories, a religious affiliated nonprofit sector does attract a special type of employee with a specific mindset and specific values. Nonetheless, it is worth noting that people who are not intrinsically motivated are not getting motivated by the faith-based surrounding. However, for people who are already motivated by what they do, they experience boosting effects in their motivation, support and encouragement to do their best.

\subsection{Benefits of a religious work environment}

\subsubsection{Spiritual nourishment}

Workplace spirituality is considered to have a positive effect on employees' performance, motivation and satisfaction. ${ }^{[5]}$ Moreover, workplace spirituality leads to increased honesty and trust within the organization. ${ }^{[17]}$ In line with the research, all participants of the study express themselves to be very delighted about working in a religious environment and perceived the working climate as very motivating and satisfying. An interviewee from the HR department simply said:

"Yes! Definitely! Their faith motivates them to create an atmosphere or create... just positivity!"

when asked if there was any impact on employees' job motivation due to the religious affiliation of the hospital.

Burack $^{[26]}$ indicated that workplace spirituality leads to an increased sense of personal fulfilment of employees and positive effects on the perceived stress level can be noticed. ${ }^{[5]}$ One of the nurses confirmed this by answering the question regarding the overall impact of the religious environment:

"But the fact that this organization provides so much positivity and so much effort on doing better and growing, keeping that in the back of your mind, when things do get rough and hard for you, than things are going to be alright. And that is part of being a faith-based organization. Things do get better." (Nurse)

Berger $^{[22]}$ revealed that one important characteristic of religiously affiliated organizations is that the intrinsic motivation is often based on and influenced by faith. By analysing several mission statements she concludes that a divine source of guidance provides a basis and template for individual development and motivation. Some interviewees indicated, very clearly, that their faith and the possibility to bring and live their faith at work supports their motivation and urges them to do better and achieve more. The following statement was an answer when asking for the most important personal motivating factor:

"Faith! Us being a faith-based organization. That gives everybody that works here in this hospital the motivation they need to carry out their jobs." (HR)

Consequently, it has to be noted, the religious and spiritual environment and the employee's own faith provide a fruitful source of inspiration and motivation for these employees to perform outstandingly, achieve excellent results for themselves and their patients, and experience positivity in their daily routine at work.

\subsubsection{High expectations}

It was mentioned remarkably often that expectations on performance are very high in this hospital not only managements' expectations but also employees' expectations to themselves. Again, this finding goes back to the religious background of the organization, as it has to accomplish its mission. Research shows that the core values of faith-based organizations are their explicit religious mission statement, including their vision and values. ${ }^{[27]}$

"Because when you have a mission statement that says to extend the Healing Ministry of Christ, you are holding yourself way above just any mission statement that is given by any company." (Nurse)

\subsubsection{Advantages over secular hospitals}

Most of the participants had worked for a few years in nonreligious corporate environments. Three participants also had professional experience outside of the healthcare sector. According to the participants, the most important difference when comparing a religiously affiliated hospital to a secular organization is the warmer atmosphere. This result is in line with the findings of Seemann et al. ${ }^{[17]}$ These authors indicated that patients perceive nonprofit hospitals to be warmer than their for-profit counterparts. Nonprofit hospitals with a religious affiliation are perceived as even warmer. During the interviews, the informant stated that employees in a faith-based organization are more tolerant, humble and dedicated, which makes it pleasant and easy to get along and work with them. Furthermore, the conversation appears to be much more pleasant and there is less profanity. One of the participants explained when asked for the most important differences:

"You know, the Chaplin, prayer services...they just offer a warm environment. A friendly environment. And you get the impression that they care for you. So that's important to me." (HR)

Another important thing that was frequently mentioned was prayer and prayer services in the hospital. It was stated that 
all meetings, at least the important ones, start with prayer. This leads to a certain community feeling and provides a special, peaceful atmosphere and awareness. The effects of prayer are often associated with those of meditation. It helps people to focus on what is important. ${ }^{[28]}$

"You know not all of our meetings begin in prayer, it's the larger ones but it reminds you of what our core values are on a continual basis. You know it reminds you that you are supposed to be forgiving and that we need to treat each other much kinder and tolerant than you would in a corporate environment." (HR)

\subsection{Challenges of a religious work environment}

The two main areas that emerged in the analysis were a lack of accountability and managers who are too compassionate. The details are discussed as follows.

\subsubsection{Lack of accountability}

Accountability is a major issue in the healthcare sector and involves the processes where a person or a party has to show responsibility. It is also an important precondition for satisfaction and loyalty towards the organization among employees. Being held accountable helps to meet standards and enables professionalism. ${ }^{[29]}$ It promotes the establishment of authority and the assignment of roles and responsibilities. Therefore, one of the management's central tasks is to hold employees accountable for their actions. The domains of accountability cover a wide range. Ebrahim and Weisband ${ }^{[30]}$ identify transparency, answerability or justification, compliance, and enforcement or sanctions as the core elements of accountability, including the acknowledgment and assumption of responsibility for actions, products, decisions, and policies. Strong leadership and adept management are important considerations for employees' motivation and engagement.

If a lack of accountability is observable on management level, extensive consequences for employee satisfaction and motivation can arise. In this study nine out of sixteen informants reported problems concerning the accountability within the organization.

"The one downside of this organization, the faith-based, is sometimes they're so busy focused on 'let's be kind and let's try to do what's best' that they forget that there still has to be accountability. We are still a business. We still have to make enough money to keep our doors open. People like me coming in from the private sector, think 'yeah we want this great and positive environment' but in the end we still have to be held accountable for our actions and our jobs. And sometimes people don't do this and this is very frustrating." (Nurse)

Published by Sciedu Press
Summarizing the answers of the participants, a lack of accountability caused by concentration on religious values is observable. According to the interviews, management is too focused on the commandments of charity and helping those who are in need. As a result there is quite frequently insufficiently considered that they have to guarantee and enforce accountability. This behavior is basically synonym to a lack of power on the management side and can therefore be considered as damaging employees working moral.

\subsubsection{Compassion}

Compassion is widely described as feeling sympathy and sorrow with somebody who is affected by unfavourable circumstances. According to McCormick, ${ }^{[31]}$ compassion can lead to an inner or moral conflict when a manager feels the need to reveal compassion while the organizational pressure forces him or her to make tough business decision. Pursuant to the participants, a faith-based environment is associated with a good-natured, understanding and forgiving working climate. It is acknowledged that everybody makes mistakes from time to time and the prevailing opinion is to be supportive and give everybody a second chance. This attitude can be obstructive and provides a challenging situation in regard to having to make critical business decisions.

"There is expectations on how we do business because of the fact that we are a Christian organization. So I think that can be challenging when you are making tough business decisions that may not be necessarily understood by everyone across all levels of the facility." (Nurse)

\section{Discussion}

The paper highlights issues to pertaining the benefits and challenges of a religious work environment, based on the example of an Adventist hospital in the USA.

It turned out that a religious work environment attracts a special type of employee with a certain pre-existing work ethic. They are mostly self-motivated and driven by the desire to help and support other members of the community. Some of the participants noted that they are motivated by faith, social and religious cohesion, and warm and sincere working relations. Nonetheless, it is worth mentioning that people who are not intrinsically motivated are not getting motivated by the faith-based surrounding. However, people who are already motivated by what they do experience boosting effects in their motivation, support and encouragement to do their best. The high expectations to themselves that are characterized by the religious affiliation help to keep standards above average. The respectful, friendly and helpful treatment of colleagues amongst each other is one of the biggest differences when compared to non-faith-based organizations. 
Participants mentioned teamwork and compassion, spiritual nourishment and an overall good feeling when coming to work. The chance to support patients, both medical and spiritual, gives their work a special meaning. This results in a fruitful and caring work environment, which leads to a stronger commitment to the organization and motivation to work.

As assumed, besides the positive aspects of the religious work environment, there are also certain challenges and disadvantages in a religious-affiliated organization that have to be taken into consideration. The demotivating factors are mostly related to management. Management that is too compassionate and a lack of accountability were observed as challenges and repeatedly mentioned by several staff members. They indicated exaggerated compassion and low accountability as a typical problem of a religious work environment, which results in dissatisfaction and incomprehension among staff members. Ebrahim ${ }^{[32]}$ suggested besides self-evaluation an generell performance assessment, codes of conduct and participatory decision processes as valuable chance of building a shared vision and therefore ensuring accountability within the organization. Lilius et al. ${ }^{[33]}$ also highlighted collective decision-making as important chance to overcome a too compassionate management. Compassion acts as an important and powerful advantage, especially in faith-based nonprofit organization, but it is certainly important to establish a common culture that addresses problems directly and visible especially when it comes to making tough but necessary business decisions.

It is evident that overall, we are moving to a more open, more diverse and more value-expressive environment. This phenomenon is not going to stop in front of organizations' gates. People are obtaining a part of their social identity from work, and therefore, there is clearly a need to meet employees' requirements for a more meaningful workplace and added work values. The study of Ibrahim and Angelidis ${ }^{[18]}$ confirmed the positive impact of a religious background on organizational performance based on the positive relationship with the staff and stakeholders. Thus, understanding the special features of a religiously affiliated organization and the effects on employees might help secular organizations provide a spiritual work environment for their employees to take advantage of the beneficial effects, without having to address the identified weaknesses. Based on these findings the following recommendations are made:

An idea that is easy for secular organizations to implement is to begin a meeting with a recurring ritual comparable to prayer. This could be a short meditation exercise, for example, that helps people to calm down and focus on the things that are important. Detached from religion, companies can offer meditation or yoga courses, teaching relaxation techniques and providing relaxation rooms. This is assumed to help employees redefine their values and mission and find their selves.

The work ethic, the working climate and the high demands on oneself that arise from the faith-supporting environment provide not only a chance for religious organizations but also the possibility to achieve growth in motivation in secular organizations if there is a chance for employees to practice and show their faith. This tolerant and supportive approach can help employees combine their private and professional lives and find the special meaning they are looking for. Even reflection on moral values without referring to a certain religion might help motivate people at work.

Defining and promoting a mission statement that illustrates the vision and values of the organization, similar to a religious mission statement, can help employees' identify more closely with the company and therefore be more loyal and set higher personal standards.

It should also be mentioned, that mixing business with religion is walking a fine line. Employees cannot be forced to engage in certain actions, such as prayer before meetings, common bible studies or community work. ${ }^{[2]}$ According to this study, there was an increase in complaints concerning religious bias over the years. However, employees might feel ruled out when not joining a religious event and therefore find themselves forced to participate. For management, it is indispensable to limit compassion in regard to tough decisions that have to be made. In addition, management has to prevent religious preferences, as they result in distrust and divisiveness. ${ }^{[5]}$

It is important to acknowledge the limitations of this study. There might be a selection bias as no data has been collected from other health facilities, several other industries and denominations. Certainly, the religious significance in the US, especially in the Bible Belt, is much higher than is the case in many European counties, for example. Therefore, it might be interesting to collect more data in an area where religious traditions are not as deeply rooted in daily life. However, this study helps to explain the motivating and demoting factors amongst staff, as well as the challenges for HR management in an Adventist Health facility.

Future research could first try to generalize the findings to other non-Adventist religious affiliations. As already mentioned, a further study in countries with a different religious mind-set would also provide a scientific benefit. Second, the findings should be verified for a non-healthcare setting. 
According to Duchon and Plowman ${ }^{[3]}$ healthcare employees already have high social values and standards and are therefore more open to their spiritual and religious needs. Another interesting field for future research is provided by the context of accountability in religious organization. The lack of accountability due to religious values is worth further examination.

\section{CONFLicts OF INTEREST Disclosure}

The authors declare they have no conflicts of interest.

\section{REFERENCES}

[1] Longenecker JG, McKinney JA, Moore CW. Religious intensity, evangelical Christianity, and business ethics: An empirical study. Journal of business ethics. 2004; 55: 371-84. http://dx. doi .org /10.1007/s10551-004-0990-2

[2] Garcia-Zamor JC. Workplace Spirituality and Organizational Performance. Public Administration Review. 2003; 63: 355-63. http: $/ / \mathrm{dx}$.doi.org/10.1111/1540-6210.00295

[3] Duchon D, Plowman DA. Nurturing the spirit at work: Impact on work unit performance. The leadership quarterly. 2005; 16: 807-33. http://dx.doi.org/10.1016/j. leaqua.2005.07.008

[4] Miller DW, Ewest T. Faith at Work (Religious Perspectives): Protestant Accents in Faith and Work. In: Neil J, (ed.). Handbook of Faith and Spirituality in the Workplace. New York: Springer; 2013. 69-84 p. http://dx.doi.org/10.1007/978-1-4614-5233-1_5

[5] Cavanagh GF, Bandsuch MR. Virtue as a benchmark for spirituality in business. Journal of business ethics. 2002; 38: 109-17. http://dx.doi.org/10.1023/A:1015721029457

[6] Chan ZC, Tam WS, Lung MK, et al. A systematic literature review of nurse shortage and the intention to leave. Journal of nursing management. 2013; 21: 605-13. http://dx.doi.org/10.1111/j.1 $365-2834.2012 .01437 . x$

[7] Pinder CC. Work motivation in organizational behavior. New York: Psychology Press; 2014.

[8] Silén M, Kjellström S, Christensson L, et al. What actions promote a positive ethical climate? A critical incident study of nurses' perceptions. Nursing Ethics. 2012; 19(4): 501-512. PMid: 22619235. http://dx.doi.org/10.1177/0969733011436204

[9] Wuthnow R. The changing nature of work in the United States: Implications for vocation, ethics and faith. The Cresset. 2003; 67: 5-13.

[10] Milliman J, Czaplewski AJ, Ferguson J. Workplace spirituality and employee work attitudes: An exploratory empirical assessment. Journal of organizational change management. 2003; 16: 426-47. http://dx.doi.org/10.1108/09534810310484172

[11] Pargament KI, Magyar-Russell GM, Murray-Swank NA. The sacred and the search for significance: Religion as a unique process. Journal of Social Issues. 2005; 61: 665-87. http://dx.doi.org/10.11 $11 / j .1540-4560.2005 .00426 . x$

[12] Neil J. Faith and Spirituality in the Workplace: Emerging Research and Practice. In: Neil J, (ed.). Handbook of Faith and Spirituality in the Workplace. New York: Springer; 2013. 3-18 p. http: //dx.doi.org/10.1007/978-1-4614-5233-1_1

[13] Bozeman B, Su X. Public Service Motivation Concepts and Theory: A Critique. Public Administration Review. 2015; 75: 700-710. http://dx.doi.org/10.1111/puar.12248

[14] Dur R, Zoutenbier R. Intrinsic motivations of public sector employees: Evidence for Germany. German Economic Review. 2014; 16: 343-366. http://dx.doi.org/10.1111/geer. 12056

[15] Wright BE, Grant AM. Unanswered questions about public service motivation: Designing research to address key issues of emer- gence and effects. Public administration review. 2010; 70: 691-700. http://dx.doi.org/10.1111/j.1540-6210.2010.02197.x

[16] Light PC. The content of their character: The state of the nonprofit workforce. The Nonprofit Quarterly. 2002; 9: 6-16.

[17] Seemann AK, Drevs F, Gebele C, et al. Are Religiously Affiliated Hospitals More Than Just Nonprofits? A Study on Stereotypical Patient Perceptions and Preferences. Journal of religion and health. 2015; 54: 1027-39. http://dx.doi.org/10.1007/s10943-014 $-9880-9$

[18] Ibrahim NA, Angelidis JP. The Long-Term Performance of Small Businesses: Are there Differences Between "Christian-Based" Companies and their Secular Counterparts? Journal of business ethics. 2005; 58: 187-93. http://dx.doi.org/10.1007/s10551-005 $-1413-8$

[19] Chou TH, Ozcan YA, White KR. Technical and scale efficiencies of Catholic hospitals: Does a system value of stewardship matter? Advanced decision making methods applied to health care. Milan: Springer; 2012. 83-101 p. http://dx.doi.org/10.1007/978-8 8-470-2321-5_6

[20] White KR, Dandi R. Intrasectoral variation in mission and values: The case of the Catholic health systems. Health Care Manage Rev. 2009; 34: 68-79. http://dx.doi.org/10.1097/01. HMR.0000 342982.14802. 47

[21] Koenig HG. Religion, spirituality, and health: the research and clinical implications. ISRN psychiatry. 2012; 2012. http://dx.doi.o $\mathrm{rg} / 10.5402 / 2012 / 278730$

[22] Berger J. Religious nongovernmental organizations: An exploratory analysis. Voluntas: International Journal of Voluntary and Nonprofit Organizations. 2003; 14: 15-39. http://dx.doi.org/10.1023 /A : 1022988804887

[23] Adventist Health System. Available from: http://www.adventis thealthsystem. com (2015, accessed 12 May 2015).

[24] Weisbrod BA. To profit or not to profit: The commercial transformation of the nonprofit sector. Cambridge University Press; 2000. http://dx.doi.org/10.1017/CB09780511625947

[25] Ben-Ner A, Ren T, Paulson DF. A sectoral comparison of wage levels and wage inequality in human services industries. Nonprofit and Voluntary Sector Quarterly. 2011; 40: 608-633. http://dx.doi.o $\mathrm{rg} / 10.1177 / 0899764010365012$

[26] Burack EH. Spirituality in the workplace. Journal of organizational change management. 1999; 12: 280-92. http://dx.doi.org/10. 1108/09534819910282126

[27] Vanderwoerd JR. How faith-based social service organizations manage secular pressures associated with government funding. Nonprofit Management and Leadership. 2004; 14: 239-62. http://dx.doi . org $/ 10.1002 / \mathrm{nml} .33$

[28] Czech DR, Wrisberg CA, Fisher LA, et al. The experience of Christian prayer in sport: An existential phenomenological investigation. Journal of Psychology \& Christianity. 2004; 23: 3-11. 
[29] Laschinger HKS, Wong C. Staff nurse empowerment and collective accountability: Effect on perceived productivity and self-rated work effectiveness. Nursing Economics. 1999; 17: 308. PMid: 10711183.

[30] Ebrahim A, Weisband E. Global Accountabilities. Cambridge: Cam bridge University Press; 2007. http://dx.doi.org/10.1017/C B09780511490903

[31] McCormick DW. Spirituality and management. Journal of managerial psychology. 1994; 9: 5-8. http://dx.doi.org/10.1108/02683
949410070142

[32] Ebrahim A. Making sense of accountability: Conceptual perspectives for northern and southern nonprofits. Nonprofit Management and Leadership. 2003; 14: 191-212. http://dx.doi.org/10.1002/n ml. 29

[33] Lilius JM, Worline MC, Dutton JE, et al. Understanding compassion capability. Human Relations. 2011; 64: 873-899. http: //dx.doi.org/10.1177/0018726710396250 